\title{
From glass walls to 'windows of opportunity'
}

Citation for published version (APA):

Ayre, E. (2021). From glass walls to 'windows of opportunity': Framing and policy processes for children affected by parental imprisonment. [Doctoral Thesis, Maastricht University]. Maastricht University. https://doi.org/10.26481/dis.20210705ea

Document status and date:

Published: 01/01/2021

DOI:

10.26481/dis.20210705ea

Document Version:

Publisher's PDF, also known as Version of record

\section{Please check the document version of this publication:}

- A submitted manuscript is the version of the article upon submission and before peer-review. There can be important differences between the submitted version and the official published version of record.

People interested in the research are advised to contact the author for the final version of the publication, or visit the DOI to the publisher's website.

- The final author version and the galley proof are versions of the publication after peer review.

- The final published version features the final layout of the paper including the volume, issue and page numbers.

Link to publication

\footnotetext{
General rights rights.

- You may freely distribute the URL identifying the publication in the public portal. please follow below link for the End User Agreement:

www.umlib.nl/taverne-license

Take down policy

If you believe that this document breaches copyright please contact us at:

repository@maastrichtuniversity.nl

providing details and we will investigate your claim.
}

Copyright and moral rights for the publications made accessible in the public portal are retained by the authors and/or other copyright owners and it is a condition of accessing publications that users recognise and abide by the legal requirements associated with these

- Users may download and print one copy of any publication from the public portal for the purpose of private study or research.

- You may not further distribute the material or use it for any profit-making activity or commercial gain

If the publication is distributed under the terms of Article $25 \mathrm{fa}$ of the Dutch Copyright Act, indicated by the "Taverne" license above, 


\section{CHAPTER EIGHT: Epilogue and valorisation addendum}

This epilogue and valorisation addendum aim to highlight the possible repercussions and impact this dissertation can have on social movement organisations, reform bodies and society in general, while tracing pathways for future advocacy. The study has explored how policy channels and framereflective advocacy can be used most efficiently to effect change and to promote meaningful action on behalf of children. As mentioned, the work carried out as part of this study has contributed to framing processes that have a purpose.

The context for advocacy for children with imprisoned parents differs from country to country and may be contingent upon such factors as differences in judicial and legal culture, human rights culture, levels of social trust/social cohesion, cultural traditions of charitable work (faith-based, secular, statefunded, etc.) or the relative impact of international and European discourse and monitoring. It has been demonstrated, for example, that moderate penal policies have their origins in a consensual and corporatist political culture, in high levels of social trust and in a strong welfare state, and conversely, that more punitive policies are present in countries where these features are less evident (Lappi-Seppäla 2011). These factors have a bearing on policies and acquis for children who have a parent in prison.

The frame-analytical lens used in this study can be adapted readily to a variety of given contexts, enhancing understanding of the cross-sectoral spheres involved in advocacy and policymaking processes for children affected by 
parental incarceration, and thus provides a model for a more fully integrated policy advocacy approach. This holds true not only for children of the incarcerated but could ultimately benefit advocacy carried out on behalf of other groups of marginalised children in situations of vulnerability, promoting the development, implementation, monitoring and evaluation of policies and services that respect their rights and protect their well-being.

Analysis of policymaking systems for marginalised children in EU member states from a framing perspective has not been carried out to date. As we have seen, due to its complex network of relevant cross-sectoral agencies involved in decision-making, the issue of children affected by parental incarceration is one offering an abundance of potential "access points" for agenda-setting. We could assume that this multiplicity may, in the end, act as a deterrent for policy outcomes in that it gives rise to competing or contending frames, diluting their impact. Reframing or frame realignment may be required to harmonise advocacy efforts by civil society organisations. The study also enhances understanding of causal effects of issue framing on decision-making within complex policymaking environments, an arena less well understood, according to Daviter (2011), than causal effects of framing on individual decision-making.

Valorisation of the study began halfway through the research. The study has placed great emphasis on exploring how the various social movement and policy framing and agenda-setting theories and analytical tools underpinning the research can be used in real-time. To this end, during the course of the research, the author has been involved in working with forty-five member organisations and individuals of a pan-European network as part of an action grant 2014-2017 to raise awareness on strategic framing, try to align frames, refine messages and maximise frame resonance in communicating positive 
solutions for children affected by parental incarceration. The overall aim has been to strengthen the impact of advocacy of individual members within their national context (some twenty countries across Europe) and to bolster the impact of this pan-European body collectively. The first step was to inventory frames (utilitarian, deontological, mixed) used by network members with respect to children who have a parent in prison. The next step was to organise two transnational workshops with leading frame analysis experts, referred by framing scholar Dvora Yanow. The first workshop, entitled Introduction to Framing as a Tool in Policy Analysis, sought to raise intra-network awareness on the importance of issue framing as a strategic tool in their advocacy work; the second, Framing and Story-telling, focused on the role of narrative storytelling to enhance the resonance and impact of messages about children with imprisoned parents.

The author has been observing the "trickle-down" effect among network members of the framing workshops, most recently with Bedford Row Family Project in Ireland, which has highlighted a greater focus on more childprotective language and framing as a primary objective in their advocacy. In addition, the Children's Ombudsman's Office in Croatia is working with stakeholders to raise their awareness on the importance of emphasising the deontological "rights-holder frame" for children, avoiding the passive "victim frame" that brings the issue into Kingdon's 'intractable issue' realm. The Expertisecentrum in the Netherlands is also working on fine-tuning framing and the language used to refer to this group of children. What is key is avoiding any further stigmatisation of children, beyond that which they frequently have to contend with having a parent in prison-Goffman's 'spoiled identity' (Goffman 1963: 130). The network plans to organise additional pan-European workshops on framing as a policy tool. One workshop will be with network members (which include members of prison services in Catalonia, Cyprus, 
Slovenia, Northern Ireland), exploring further how the complex and challenging issue of children of the incarcerated might best be communicated, with a particular focus on the ways in which individual member organisations that are part of larger advocacy coalitions might be identifying, representing and giving legitimacy to the issue of children who have a parent in prison. An overall question to explore is whether some individual network members may be targeting different agendas, and if the use of contending frames could be somehow diluting the impact of collective advocacy. Discussions can revolve around whether these competing frames might be 'reframed' or 'bridged' to intensify impact. A second workshop would bring in likeminded child welfare and child rights NGOs and civil society organisations who could ultimately benefit from the learning, thus mainstreaming it. The pan-European advocacy coalition is active in lobbying the European Union in tandem with the Brusselsbased Child Rights Action Group, an informal consortium of NGOs working to promote the EU Strategy on Child Rights on behalf of children in vulnerable situations. One of the workshops mentioned would involve children and young people, and their voices, experiences and advice could further inform messages and advocacy work, thus integrating a child safeguarding mechanism into framing processes while fine-tuning the messages conveyed. Another strand of the pan-European advocacy coalition's work is participating in an expert group on children with imprisoned parents (2019-2021), organised by EuroPris, a Brussels-based umbrella NGO comprised of EU member state prison services. Through its participation in the expert group, the pan-European coalition has introduced this new learning and awareness on framing into sessions with prison services across Europe, on the role and importance of language in shaping the reality of children of the incarcerated, and of construing them as rights-bearers with agency who can be involved in decisions impacting their lives. In short, framing and agenda- 
setting theories have been integrated into the advocacy coalition's programmatic and operational activities, and will be integral to networking with stakeholders; communication via social media and the development of future projects. Emphasis on framing and agenda-setting is included in all reporting to the European Union, thus heightening its visibility and enhancing its importance and relevance in other EU-funded projects. When asked for a testimonial on what the European Union can do for children in future, as part of preparations for the EU Forum on Child Rights 2020, the author responded that the EU could focus more on how language about children in vulnerable situations is formulated and be made more protective, with specific attention to referring to these children as rights-holders who have agency, not as passive victims, subjected to their lot. 